\title{
Molluscum Contagiosum Viral Infection Treated With a Dilute Povidone-Iodine/Dimethylsulfoxide Preparation
}

\author{
Kara Capriotti $\cdot$ Kevin Stewart $\cdot$ Jesse Pelletier $\cdot$ Joseph Capriotti
}

To view enhanced content go to www.dermtherapy-open.com

Received: November 19, 2015 / Published online: December 21, 2015

(C) The Author(s) 2015. This article is published with open access at Springerlink.com

\section{ABSTRACT}

Introduction: Molluscum contagiosum is a viral infection of the skin that is spread from direct contact, either via person to person by touching affected lesions or innocuously via fomites. The condition is often socially stigmatizing, motivating patients to seek treatment. There are many anecdotal remedies, but none have been overwhelmingly effective in controlled clinical trials.

Case Report: A 16-year-old girl presented with approximately 75 lesions on her inner thighs as

Electronic supplementary material The online version of this article (doi:10.1007/s13555-015-0091-4) contains supplementary material, which is available to authorized users.

K. Capriotti $(\bowtie) \cdot$ K. Stewart · J. Pelletier .

J. Capriotti

Veloce BioPharma LLC, Fort Lauderdale, FL, USA

e-mail: karacapriotti@gmail.com

K. Capriotti

Bryn Mawr Skin and Cancer Institute, Rosemont, PA, USA

K. Stewart · J. Pelletier · J. Capriotti

Plessen Ophthalmology Consultants, Christiansted, VI, USA a result of friction from an athletic uniform. She tried over-the-counter antibiotic ointment and topical steroids for several weeks without improvement, and was concerned at the rate of spread of the lesions, along with the social implications.

Conclusion: The topical povidone-iodine/ dimethylsulfoxide system is very effective in eradicating molluscum contagiosum. This novel combination warrants further investigation in randomized, controlled trials to further elucidate its clinical utility.

Keywords: Dimethylsulfoxide; Molluscum contagiosum; Povidone-iodine

\section{INTRODUCTION}

Molluscum contagiosum (MC) is a viral infection of the skin caused by a DNA poxvirus called the molluscum contagiosum virus. MC is spread from direct contact, either via person to person by touching affected lesions or innocuously via fomites. The skin infection is most common in children and sexually active adults. MC can affect any area of the skin, and remains infectious until the 
lesions have resolved. Most lesions will resolve without treatment, with the average length of infection lasting between 6 and 18 months [1]. The condition is often socially stigmatizing and patients subsequently seek treatment. Though there are many anecdotal remedies, none have been shown to be universally effective as a take-home prescription option in controlled clinical trials.

\section{CASE REPORT}

A 16-year-old girl presented with a 4-week history of an asymptomatic rash on the superior medial thighs. It started as several lesions on the right thigh and over the next several weeks spread towards the knee and the adjacent thigh. She admitted to continuous friction in the area from a field hockey uniform. Physical examination revealed approximately 75 skin colored umbilicated papules, with several demonstrating varying degrees of inflammation. Over-the-counter topical antibiotic ointment and topical steroids were tried for duration of 2 weeks prior to the visit without improvement. A diagnosis of MC was made.

The patient was given a topical solution of $1 \%$ povidone-iodine (PVP-I) in a dimethylsulfoxide (DMSO) vehicle that was prescribed from a licensed compounding pharmacy. The solution was applied twice daily. At the 3-week follow-up visit, approximately half of the lesions had resolved and no new lesions had appeared. By 6 weeks there was complete resolution. Besides mild dryness at the application site, the patient denied any side effects from treatment. Informed consent was obtained from all patients for being included in the study.

\section{DISCUSSION}

MC, although medically benign, is a readily spread viral infection that can be cosmetically disfiguring, prompting many to seek treatment. The only FDA-approved treatment is the in-office application of cantharidin, which works mechanistically via selective acantholysis intraepidermally, inducing a blister at the involved skin site [2, 3]. Local destruction can also be achieved off label via curettage, laser, cryotherapy or needle extraction, but these are painful and not tolerated well by children. Lesion eradication may also be chemical (trichloroacetic acid, tretinoin), or immunologic (imiquimod), inciting an inflammatory response which upregulates the immune system to clear the infection [4]. Topical cidofovir has been used in the immunosuppressed population, but has not been systemically studied in the general population $[5,6]$. This is the first case report of a broad-spectrum anti-microbial demonstrating efficacy in this common condition.

PVP-I is used primarily in dermatology as a surgical preparation as it has been recognized as a broad spectrum, resistance-free biocidal agent for many years. Though incompletely understood, it is likely that free iodine poisons electron transport, inhibits cellular respiration, destabilizes membranes, inhibits protein synthesis and denatures nucleic acids. Although PVP-I kills microorganisms including bacteria, viruses, yeasts, molds, fungi and protozoa, it has scarcely been used for purposes outside of skin asepsis in dermatology [7].

DMSO is a very effective pharmaceutical vehicle, greatly enhancing percutaneous penetration when used in combination with other substances. DMSO facilitates diffusion through the stratum corneum, triggers the 
formation of drug deposition in the dermis, and promotes transport into local blood vessels [8]. Compounded PVP-I in a DMSO vehicle is commonly used in our practice for a variety of indications such as onychomycosis, verruca vulgaris, chemotherapy-associated paronychia, and granulation tissue.

\section{CONCLUSION}

We have had remarkable success with this novel combination. The lack of prescription FDA-approved therapies presents both a clinical dilemma for the practitioner and the patient as current at-home treatments are used primarily in the pediatric population. The topical povidone-iodine/DMSO system we have pioneered has been very effective in eradicating widespread disease. This novel combination warrants further investigation in randomized, controlled trials to further elucidate its clinical utility with the aim of enabling an eventual FDA approval for this currently unmet need.

\section{ACKNOWLEDGMENTS}

No funding or sponsorship was received for this study or publication of this article. All named authors meet the International Committee of Medical Journal Editors (ICMJE) criteria for authorship for this manuscript, take responsibility for the integrity of the work as a whole and have given final approval to the version to be published.

Disclosures. K. Capriotti, K. Stewart, J. Pelletier and J. Capriotti have nothing to disclose.

Compliance with ethics guidelines. Informed consent was obtained from all patients for being included in the study.
Open Access. This article is distributed under the terms of the Creative Commons Attribution-NonCommercial 4.0 International License (http://creativecommons.org/licenses/ by-nc/4.0/), which permits any noncommercial use, distribution, and reproduction in any medium, provided you give appropriate credit to the original author(s) and the source, provide a link to the Creative Commons license, and indicate if changes were made.

\section{REFERENCES}

1. Hansen D, Diven DG. Molluscum contagiosum. Dermatol Online J. 2003;9(2):2.

2. Haddad V, Cardoso JL, Lupi O, et al. Tropical dermatology: venomous arthropods and human skin: part 1. Insecta J Am Acad Dermatol. 2012;67(3):331.e1-14.

3. Bertaux B, Prost C, Heslan $M$, et al. Cantharide acantholysis: endogenous protease activation leading to desmosomal plaque dissolution. $\mathrm{Br} \mathrm{J}$ Dermatol. 1988;118(2):157-65.

4. Stulberg DL, Hutchinson AG. Molluscum contagiosum and warts. Am Fam Physcian. 2003;67(6):1233-41.

5. Foissac M, Goehringer F, Ranaivo, et al. Efficacy of safety of intravenous cidofovir in the treatment of giant molluscum contagiosum in an immunosuppressed patient. Ann Dermatol Venereol. 2014;141:620-2.

6. Toutous-Trellu L, Hirschel B, Piguet V, et al. Treatment of cutaneous human papilloma virus, poxvirus and herpes simplex virus infections with topical cidofovir in HIV positive patients. Ann Dermatol Venereol. 2004;131(5):445-9.

7. Capriotti K, Capriotti JA. Topical iodophor preparations: chemistry, microbiology, and clinical utility. Dermatol Online J. 2012;18(11):1.

8. Capriotti K, Capriotti JA. Dimethyl sulfoxide: history, chemistry, and clinical utility in dermatology. J Clin Aesthet Dermatol. 2012;5(9):24-6. 